Animal Health Research Institute, Ismailia Branch.

\title{
STUDIES ON MICROSPORIDIOSIS AMONG SOME MARINE FISHES AND THEIR ASSOCIATED PATHOLOGICAL LESIONS
}

(With 2 Tables and 6 Figures)

By

HEBA I. ABDEL-MAWLA and SOHAIR Y. MOHAMED (Received at 3/3/2010)

دراسات على مرض الميكروسبوريديا فى بعض الأسماك البحريه والتغيرات البهات البهات

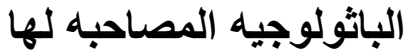

هبه إبراهيم عبل المولمى ، سهير يوسف محمد

أجريت هذه الدر اسة على مرض الميكروسبوريديا فى بعض أسماك المياه المالحة منها

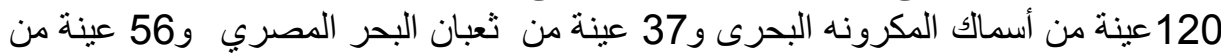

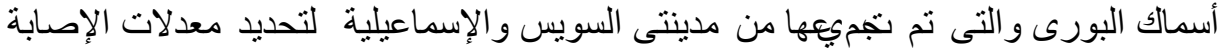

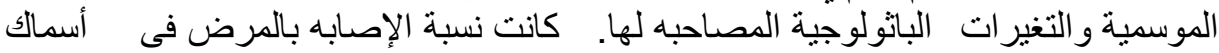

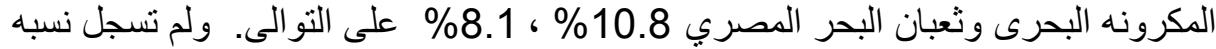

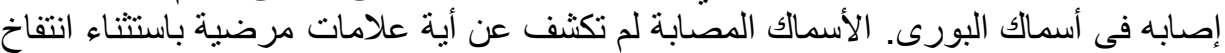

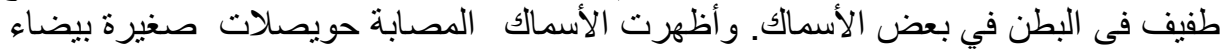

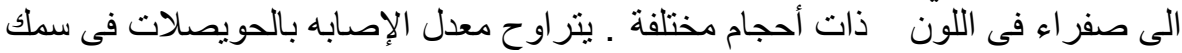

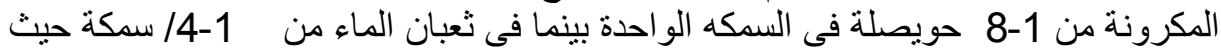

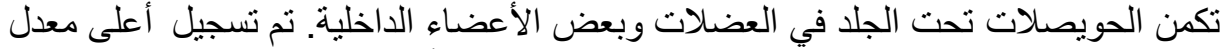

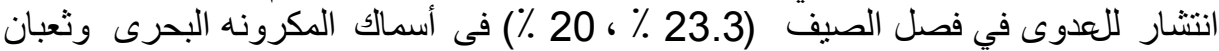

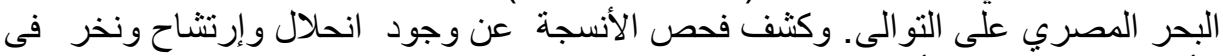
الأعضاء و عضلات الأسماك المصابة.

\section{SUMMARY}

A total of 120 hake fish (Saurus tumbil); 37 Egyptian eel (Anguilla anguilla) and 56 Mugil sp. (Mugil cephalus) were collected from Ismailia and Suez Province to investigate the seasonal prevalence of microsporidiosis and the associated pathological changes. The infestation rates in Saurus tumbil, Anguilla anguilla and Mugil cephalus were $10.8 \%, 8.1 \%$ and $0 \%$ respectively. The infected fish revealed no pathognomonic clinical signs except slight abdominal distension in some 
fish. The fish specimen showed small white to yellowish-white cysts or nodules with different sizes and the intensity of nodules was 1-8 per fish in Saurus tumbil and 1-4/fish in Anguilla anguilla which embedded subcutaneously in the musculature and some internal organs. The highest prevalence of infection was recorded in summer $(23.3 \%, 20 \%$ and $0 \%$ in Saurus tumbil, Anguilla anguilla and Mugil cephalus respectively). The histopathological examination revealed degeneration, oedema and necrosis in organs and muscles of the infected fishes.

Key words: Microsporidiosis, marine fishes, pathological lesions.

\section{INTRODUCTION}

Microsporidiosis is considered the most economically important diseases of marine fish. Microsporidia are minute, unicellular organisms living as obligate intracellular parasites in a variety of animal hosts (Didier et al., 2004). Eleven genera had been known to infect fish tissues of these seven ones were specific for fish (Lom and Dykova, 1992). Several species of microsporidia were reported from the musculatures of fish causing severe diseases and low productivity of fisheries, such as Pleistophora duodecimae, P. ladogensis. P. mirandellae and Heterosporis schuberti (Lom et al., 1980 and 1989; Kepr, 1991). Microsporidiosis is a serious chronic debilitating and potentially lethal disease of high morbidity rate (Eissa, 2002), and characterized by the production of spores, they are usually parasites of invertebrates but are also widely distributed in Teleosts in freshwater estuarine and marine habitats. Microsporidiosis may constitute one of the limiting factors which affect the growth of fish stocks with consequent reduce productivity in fisheries (Dykova, 1995). Fish Microsporidia are embedded directly in the cytoplasm of the host cell which they actually destroy or they induce enormous hypertrophy of the cell (Lom and Nilsen, 2003). The prevalence of microsporidia in Egyptian eel was $8.69 \%$ (Abdel-Aal, 2002). The aim of this work is to investigate the clinical and postmortem lesions as well as the seasonal infestation rate among the infested marine fishes. The histopathological alterations were also considered.

\section{MATERIALS and METHODS}

Fish: A total number of 213 freshly caught marine fish; 120 hake fish (Saurus tumbil), 37 Egyptian eel (Anguilla anguilla) and 56 Mugil sp. 
(Mugil cephalus) were randomly collected at the different season from the Ismailia and Suez Province.

Clinical and Post-mortem examination of fish: The collected fish samples were examined carefully, externally and internally for detection of protozoan cysts and any abnormalities. Gills, fins, skin, branchial cavity, s/c tissues, musculatures and internal organs were submitted for examination according to Conroy and Hermann (1981).

Parasitological examination: The fish was examined carefully for parasites, the suspected cysts were squashed between two glass slides, and impression smears were done, fixed in absolute methyl alcohol then stained with Giemsa's stain for microscopically identification according to Lom and Dykova (1992) and Woo (1995).

Histopathological examination: Small pieces of suspected lesions with cysts were preserved in $10 \%$ neutral buffered formalin. The specimens were dehydrated in ascending grades of ethyl alcohol then cleared in xylol and embedded in paraffin wax. Serial section of 5um thickness were obtained and stained with Hematoxyline and Eosin (H\&E) according to Drury and Willington (1980).

\section{RESULTS}

\section{Clinical and Postmortem examination:}

The clinical signs of most examined fish revealed no pathognomonic clinical abnormalities. Some infested fishes showed slight distension of abdomen in some hake-fish. The infested marine fish revealed subcutaneous cysts varying in shape as round or oval and varying in colour from white to yellowish-white in hake-fish and Egyptian eel. The nodules of hake-fish were found in different internal organs as intestine, liver and embedded or attached in musculature (Fig. 1-A \& B). But the cysts of eel were found in musculature, appeared as white spots slightly bulging under the skin. The cysts were grossly observed and could be easily collected from the infected fishes (Fig. 2). There were no nodules found in Mugil cephalus.

\section{Parasitological examination:}

The infested marine fish (hake and eel) revealed white to yellowish nodules (xenomas) measuring from 1 up to $10 \mathrm{~mm}$ in diameter. The number of cyst-like structure was 1-8 cyst/hake-fish which found in different internal organ and muscles. Meanwhile, the number of cyst in muscles of Egyptian eel was 1-4 cyst/fish (Table 1). Milky-material oozed, when the cysts squashed between two slides. 
Microscopically, it showed thick wall, pyriform or egg-shaped with large posterior vacuoles and one polar cap in different sizes (spores) (Fig. 3-A and B). They were identified as Microsporidian protozoan Glugea species in hake-fish and Pleistophora (Heterosporis sp.) in Egyptian eel (Fig. 3-C).

\section{Prevalence and seasonal variation of microsporidiosis:}

In hake-fish, the highest infestation rate was recorded in summer (23.3\%) followed by spring (13.3\%), autumn (6.7\%) while there was no recorded infestation during winter. The total prevalence of microsporidiosis was $(10.8 \%)$ in hake fish. Similarly, the total prevalence in eel (A. anguilla) was $(8.1 \%)$. The highest infestation rate was recorded in summer $(20 \%)$ followed by spring $(11.1 \%)$ while there was no recorded infestation in autumn and winter. Mugil cephalus revealed no microsporidian nodules in any organs (Table 2).

Table 1: The intensity of microsporidian cyst-like structure in some marine fish (Saurus tumbil, Anguilla anguilla and Mugil cephalus).

\begin{tabular}{|c|c|c|c|}
\hline No. of cyst & $\begin{array}{c}\text { No. of infested } \\
\text { saurus tumbil }\end{array}$ & $\begin{array}{c}\text { No. of infested } \\
\text { A. Anguilla }\end{array}$ & $\begin{array}{c}\text { No. of infested } \\
\text { Mugil cephalus }\end{array}$ \\
\hline $1-2$ & 6 & 2 & 0 \\
\hline $3-4$ & 4 & 1 & 0 \\
\hline $5-6$ & 2 & 0 & 0 \\
\hline $7-8$ & 1 & 0 & 0 \\
\hline Total & 13 & 3 & 0 \\
\hline
\end{tabular}

Table 2: Seasonal prevalence of microsporidiosis in some marine fish (Saurus tumbil, Anguilla anguilla and Mugil cephalus).

\begin{tabular}{|l|c|c|c|c|c|c|c|c|c|}
\hline \multirow{2}{*}{ Season } & \multicolumn{3}{|c|}{ Saurus tumbil (hake) } & \multicolumn{3}{c|}{ Anguilla anguilla (eel) } & \multicolumn{3}{c|}{ Mugil cephalus } \\
\cline { 2 - 11 } & $\begin{array}{l}\text { No of } \\
\text { exam. }\end{array}$ & $\begin{array}{l}\text { No of } \\
\text { infect. }\end{array}$ & $\%$ & $\begin{array}{l}\text { No of } \\
\text { exam. }\end{array}$ & $\begin{array}{l}\text { No of } \\
\text { infect. }\end{array}$ & $\%$ & $\begin{array}{l}\text { No of } \\
\text { exam. }\end{array}$ & $\begin{array}{l}\text { No of } \\
\text { infect. }\end{array}$ & $\%$ \\
\hline Spring & 30 & 4 & 13.3 & 9 & 1 & 11.1 & 12 & 0 & 0 \\
\hline Summer & 30 & 7 & 23.3 & 10 & 2 & 20 & 16 & 0 & 0 \\
\hline Autumn & 30 & 2 & 6.7 & 8 & 0 & 0 & 13 & 0 & 0 \\
\hline Winter & 30 & 0 & 0 & 10 & 0 & 0 & 15 & 0 & 0 \\
\hline Total & 120 & 13 & 10.8 & 37 & 3 & 8.1 & 56 & 0 & 0 \\
\hline
\end{tabular}

\section{Histopathological examination of the infested fish:}

Microscopical examination of muscles of infested eel with microsporidia revealed melanomacrophage, sever muscular 
degeneration, necrosis and edema in the muscle fibers with presence of sporocysts (Fig. 4-A and B). Muscles of infected hake-fish showing edema, sever necrosis with the presence of mononuclear cells infiltrations in between the muscle fiber. (Fig.5-A). Myocardiam exhibiting edema, sever necrosis, mononuclear cell infiltration and presence of melanomacrophage cells (Fig.5-B) liver of hake fish showing Glugea cysts with sever necrotic hepatocytes and edema (Fig.6).
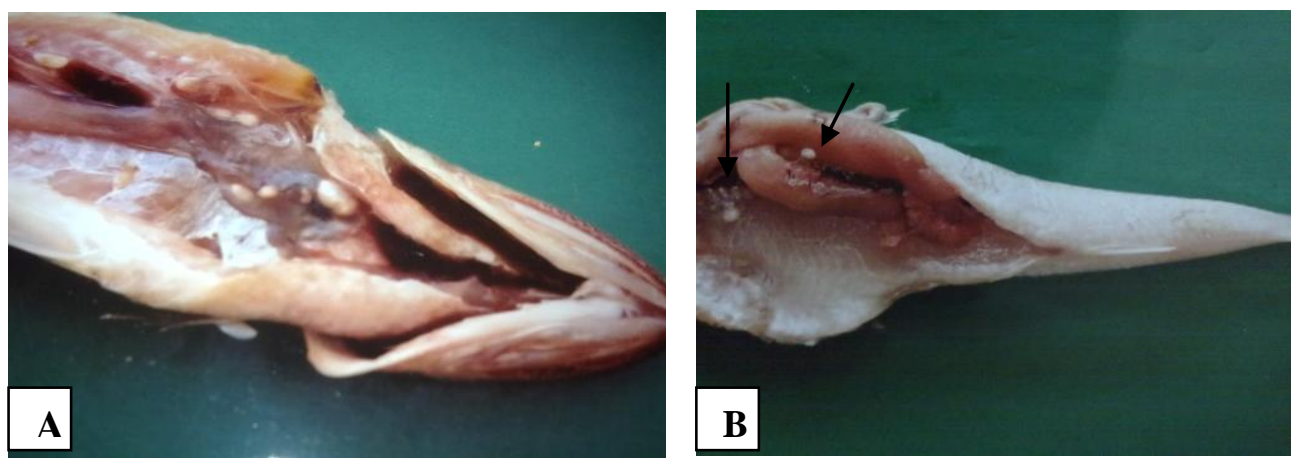

Fig. 1: A\&B: Hake-fish (Saurus tumbil) showing different size and shape of Glugean cyst.

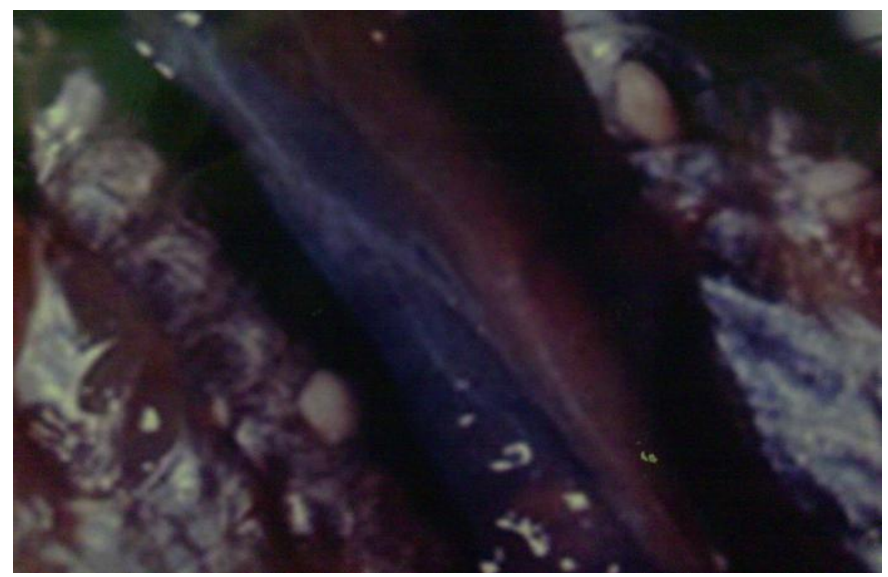

Fig. 2: Eel-fish (Anguilla anguilla) showing Pleistophora cyst 

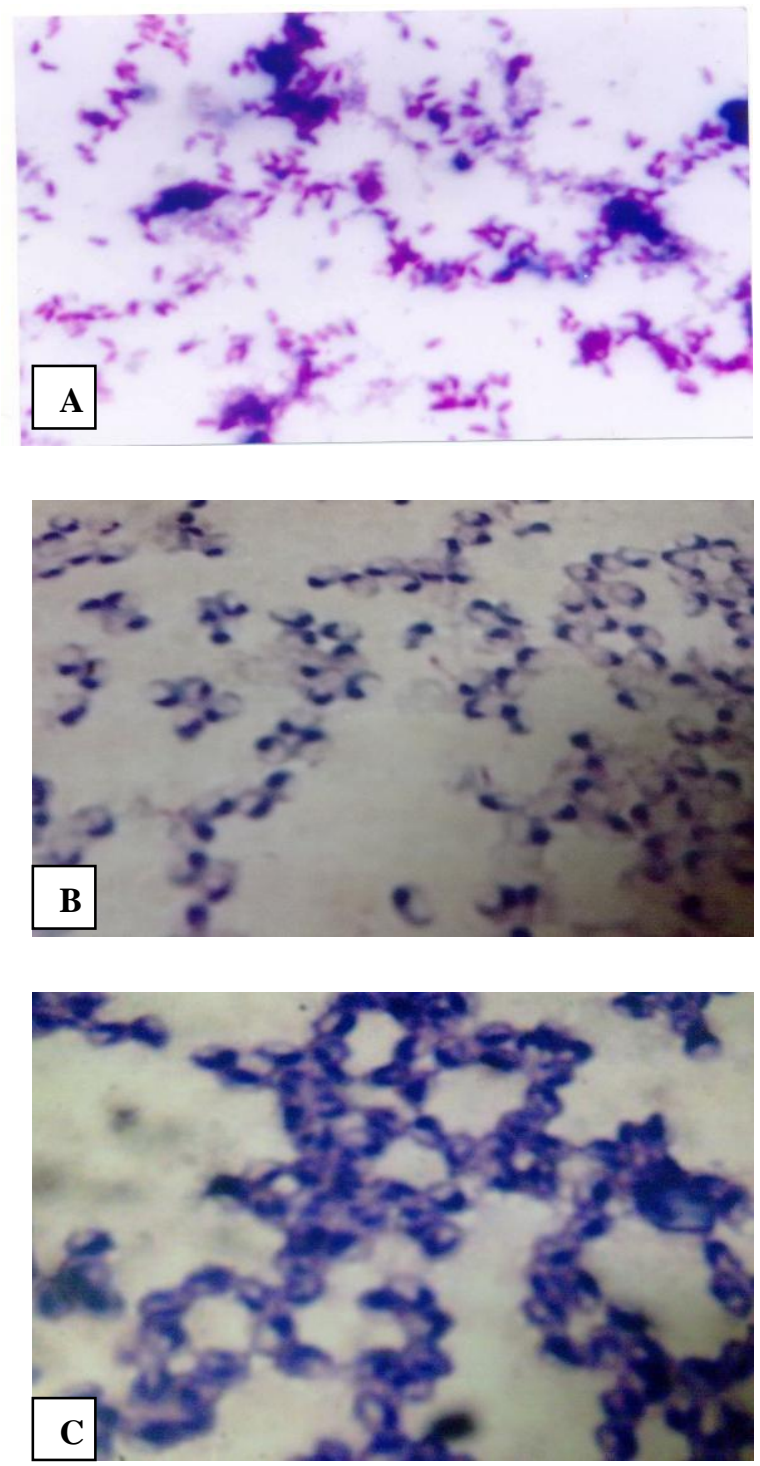

Fig. 3: A: Spores of Glugea sp. isolated from hake-fish (Saurus tumbil), stained with Giemsa. B: Spores from hake-fish showing large posterior vacules \& polar cap. C: Spores isolated from eel (Anguilla anguilla), stained with Giemsa 

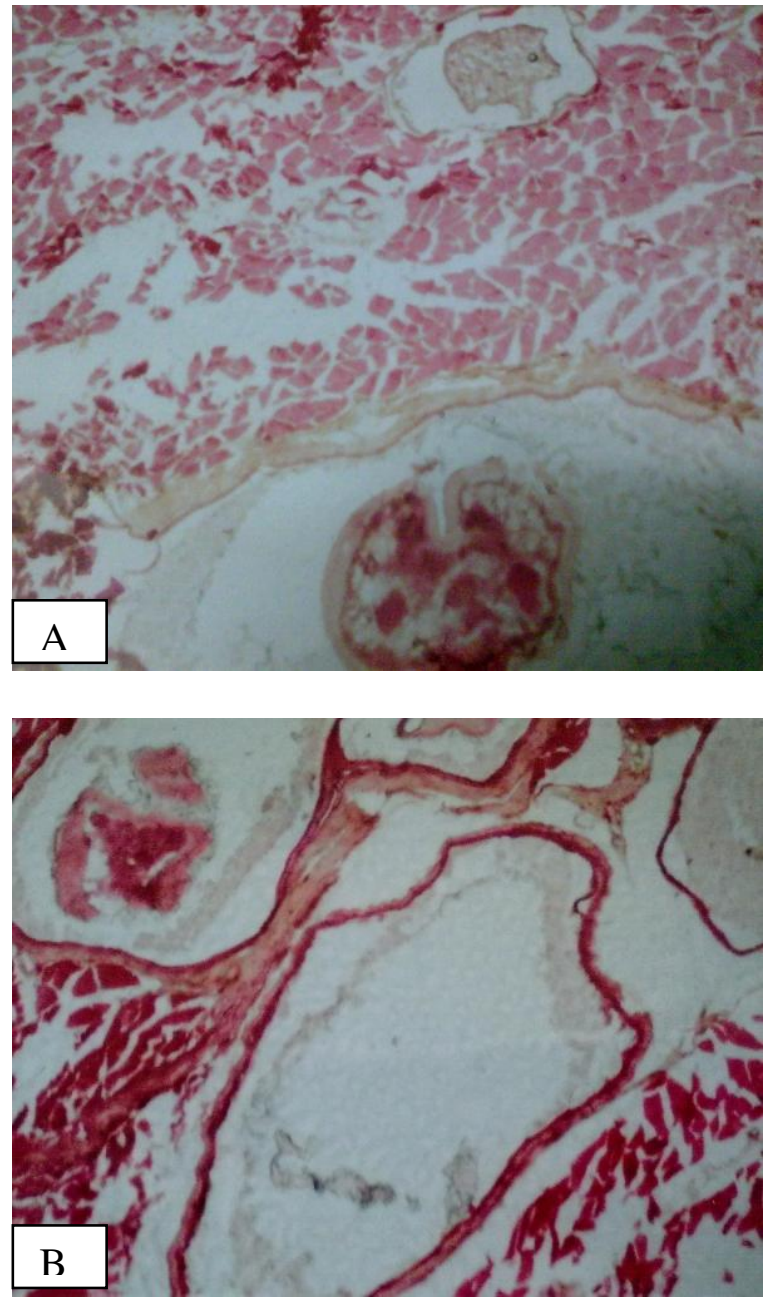

Fig.4: A: Muscles of infested eel with microsporidia revealed melanomacrophage, severe muscular degeneration, necrosis and edema in the muscle fibers with presence of sporocysts. B: high power of A. 

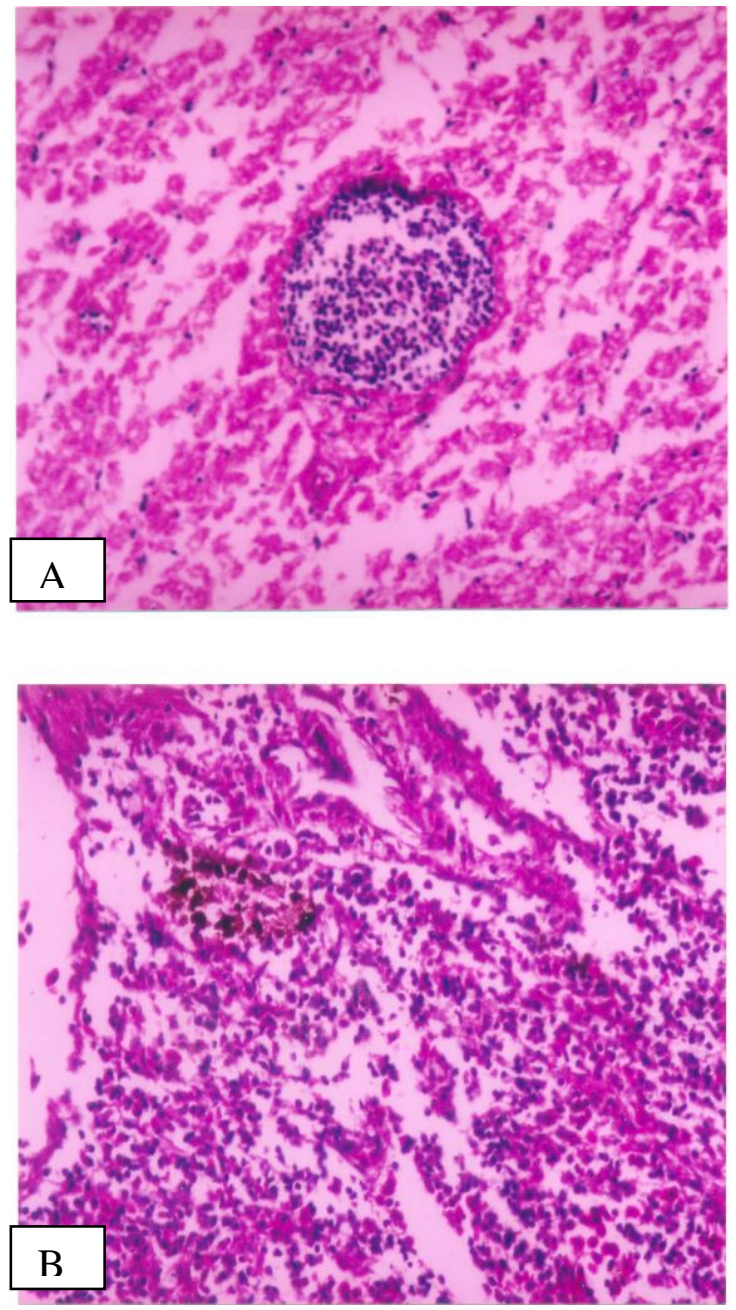

Fig. 5: A: Muscles of infected hake-fish showing edema, severe necrosis with the presence of mononuclear cells infiltrations in between the muscle fiber. (H\&E x250).

B: Myocardiam exhibiting edema, severe necrosis, mononuclear cell infiltration and presence of melanomacrophage cells (H\&E x100) 


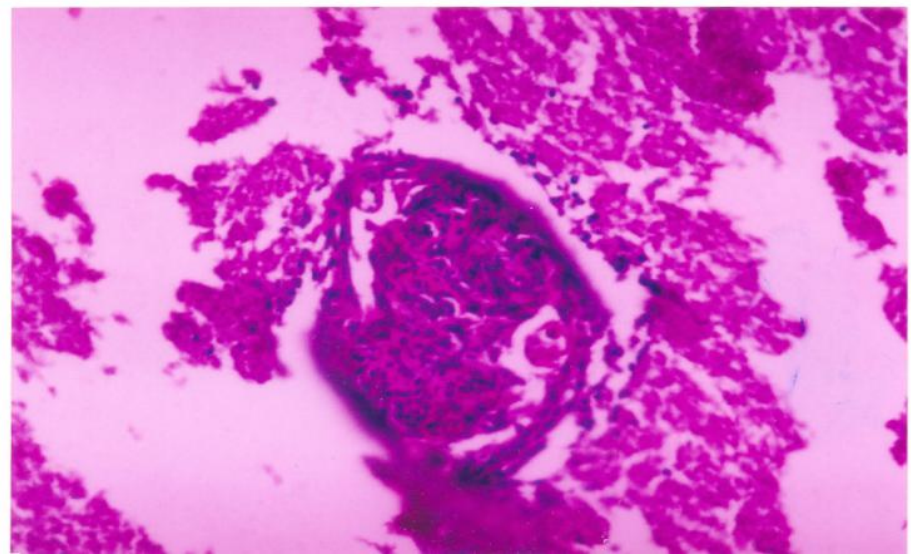

Fig. 6: liver of hake fish showing Glugea cysts with severe necrotic hepatocytes and edema (H\&E x100).

\section{DISCUSSION}

The infested marine fish (hake and eel) with microsporidia revealed no pathognomonic clinical signs related to such disease except slight abdominal distension in some fish, similar findings were recorded by Eissa (1995, 2002); Walaa El-Shaer, (2004); Peyghan, et al. (2009). Meanwhile, post-mortem examination reveals presence of numerous cyst like nodules (xenomas) varying in shape and colour ranging from white to yellowish, they were found in different organs such as stomach, heart, intestine and abdominal cavity musculature. These descriptions were nearly similar to the findings reported by Eissa, (1995); Noga, (1996); Yokoyama, et al. (2002); Walaa El-Shaer, (2004); Casal, et al. (2008) and also supported by the results that given by Barber et al. (2009) who recorded that microsporidiosis caused subcutaneous creamy-white patches in the body musculature in marine Goby. Baquero et al. (2005) found the same investigation in the trunk muscle of commercial hake from Namibia.

This protozoan species was manifested by the presence of small white to yellowish white cysts embedded subcutaneously in musculature of eel. This manifestation was observed by T'sur and wang (1988) in Japanese eel, in Egyptian eel (Abdel- Aal, 2002) and in farm eel in Korea (Seong Joon Joh et al., 2007).

The intensity of nodules in hake fish varied from lup to 8/fish. This result is lower than the findings reported by Eissa (1995) 3-56/fish, but nearly similar to Walaa El-Shaer (2004) 1-13/fish. The total prevalence of infestation was $10.8 \%$, it was lower than that obtained by 
Eissa (1995) 43\%. However, the highest infestation rate was recorded in summer $23.3 \%$ followed by spring $13.3 \%$ then autumn $6.7 \%$ and winter $0 \%$, these results were nearly similar to Eissa (1995); Abd El-Aal (2002)* who reported that the highest infestation rate was recorded in summer but the rate increased than that recorded in the current study. This result agrees with Ebrahim and Mona (2000) who found that the infection was higher in summer followed by spring, autumn and winter. The difference in the results could be attributed to the time of investigation \& low or heavy infestation. The result also indicated that the total prevalence in Egyption eel was $8.1 \%$, which agreed with that reported by Abdel- Aal (2002). Meanwhile, the highly infestation rate was observed in summer $20 \%$ followed by spring $11 \%$ and no record observed in autumn or winter season. This findings agree with Seong Joon Joh et al. (2007) who mentioned that the development of microsporidia is dependent on the water temperature. When the temperature is between $15-30^{\circ} \mathrm{C}$, spores begin to develop, causing the disease. When the temperature is $>25{ }^{\circ} \mathrm{C}$, disease appears earlier and gross lesions can be detected within 20 days from infection. Muscles of infested eel with microsporidia revealed sporocysts and hyaline degeneration in the muscle fibers and lymphocytic inflammation. This findings agree with (Abd El-Aal, 2002; Seong Joon Joh, et al., 2007) who found sporocysts and hyaline degeneration in the muscle fibers and diffused severe lymphocytic inflammation in the muscle tissue while Muscles of infected hake-fish showing edema, sever necrosis with the presence of mononuclear cells infiltrations in between the muscle fiber. Myocardiam exhibiting edema, sever necrosis, mononuclear cell infiltration and presence of melanomacrophage cells. Liver of hake fish showing Glugea cysts with sever necrotic hepatocytes and edema. These results were nearly similar to Walaa El-Shaer (2004) who found oedema, degenration and Zenker,s necrosis in musculature. The heart revealed oedema, numerous mononuclear lymphocytes and necrosis.the liver contained spores and cysts with pressure atrophy, degeneration and necrosis.

\section{REFERENCES}

Abdel Aal, A.A. (2002): Heterosoris (Pleistophora) Anguillarum (Protozoa:Microsporidia) in the musculature of the Egyptian Eel (Anguilla Anguilla). SCVMJ, V (1), 17: 25.

Abd El-Aal, A.M. (2002): Studies on some tissue parasites in fish.Ph.D.Vet. Sc. Thesis, Tanta Univ. 
Barber, I.; Davies, A.J.; Ironside, J.E.; Forsgren, E. and Amundsen, T. (2009): First record of a Kabatana sp. microsporidium infecting fish in the Atlantic Ocean._Dis Aquat Organ. 2009 Feb. 12; 83(2):145-52.

Baquero, E.; Rubio, M.; Moura, IN.; Pieniazek, NJ. and Jordana, R. (2005): Myosporidium merluccius n.g., n. sp. infecting muscle of commercial hake (Merluccius sp.) from fisheries near Namibia.J. Eukaryot Microbiol. 52(6): 476-483.

Casal, G.; Matos, E.; Teles-Grilo, M.L. and Azevedo, C. (2008): A new microsporidian parasite, Potaspora morhaphis n. gen., n. sp. (Microsporidia) infecting the Teleostean fish, Potamorhaphis guianensis from the River Amazon. Morphological, ultrastructural and molecular characterization. Parasitology. Aug; 135(9):1053-64.

Conroy, D.A. and Hermann, L.R. (1981): Textbook of fish diseases. T.F.H. Publ., West Sylvania.

Didier, ES.; Stovall, ME.; Green, LC.; Brindley, PJ.; Sestak, K. and Didier, PJ. (2004): Epidemiology of microsporidiosis: sources and modes of transmission. Vet. Parasitol., 126: 145-166.

Drury, R.A. and Willington, E.A. (1980): Carleton's Histological Techniques $5^{\text {th }}$ ed Oxford, New York.

Dykova, I. (1995): Phylum Microspora. Fish diseases and disorders (Woo, P. T.K.) volume 1. protozoan and metazoan infection 149-179.

Ebrahim, M.M. and Mona, H. Khattab (2000): Histopathological and parasitological investigation on microsporidian infection in muscular tissue of marine fish at the eastern province of Saudi Arabia. J. Egypt. Vet. Med. Assoc. 60, 1: 79-87.

Eissa, I.A.M. (1995): Studies on parasitic diseases in marine Hake fish (Saurus tumbil) for the first time in Egypt. Zag. Vet. J., 23, 4, 90-93.

Eissa, I.A.M. (2002): Parasitic fish diseases in Egypt. Dar El-Nahda ElArabia Publishing, 32 Abd El-Khalek Tharwat St. Cairo, Egypt.

Kepr, T. (1991): Parasitic protozoa of cyprinid fishes: Protozoa of the roach, Rutilus rutilus (Linnaeus, 1758) in Czechoslovakia. Folia Parasitol., 38: 11-21.

Lom, J.; Gaevskaya, A. and Dykova, I. (1980): Two microsporidia parasites found in marine fishes in Atlantic Ocean. Folia Parasitol., 27: 197-202. 
Lom, J.; Dykova, I.; Korting, W. and Klinger, H. (1989): H-elerosporis schuberti n.sp. a new microsporidian parasites of aquarium fish. Eur. J. Parasitol., 25: 129-135.

Lom, J. and Dykova, I. (1992): Developments in Aquacultures and Fisheries Science, 26. Protozoan Parasites of Fishes. Elsevier Amsterdam. Pp.125-157.

Lom, J. and Nilsen, F. (2003): Fish Microsporidia: fine structural diversity and phylogeny. Int. J. Parasitol., 33: 107-127.

Noga, E.J. (1996): Fish Disease: Diagnosis and Treatment.Copyright Mosby-Year Book, Watsworth Publishing Co., USA.

Peyghan, R; Nabavi, L.; Jamshidi, K. and Akbari, S. (2009): Microsporidian infection in lizardfish, Saurida undosquamis of Persian Gulf. Iranian Journal of Veterinary Research, Shiraz University, Vol. 10, No. 2, Ser. No. 27.

Seong Joon Joh; Yong Kuk Kwon; Min Chul Kim; Min Jeong Kim; Hyuk Man Kwon; Jung Won Park; Jun Hun Kwon and Jae Hong Kim (2007): Heterosporis anguillarum infections in farm cultured eels (Anguilla japonica) in Korea. J.Vet. Sci. (2007), $8(2), 147-149$.

Tsur, W. and Wang, C. (1988): On the Pleistophora infection in eel. IHistopathlogy, ultrastructure and development of Pleistophora anguillarum in eel, Anguilla japonica. Bull. Inst. Zool. Acad.Sin. Taiwan, 27: 159-166.

Walaa El-Shaer (2004): Studies on microsporidiosis in cultured and wild fishes. M.V.Sc. Thesis. Faculty of Vet. Med., Suez Canal University.

Woo, P.T.K. (1995): Fish diseases and disorders Vol. 1 (protozoan and metazon infections) $\mathrm{CAB}$, Int., Wallingford, Oxan, UK.

Yokoyama, H.; Lee, S.J. and Bell, A.S. (2002): Occurrence of a new microsporidium in the skeletal muscle of the flying fish Cypselurus pinnatibarbatus japonicus (Exocoetidae) from Yakushima, Japan. Folia Parasitol (Praha). 49(1): 9-15. 